\title{
Propagation of three Blue Honeysuckle (Lonicera caerulea L.) cultivars in in vitro culture
}

Razmnožavanje tri kultivara sibirske borovnice u in vitro kulturi

Ines Mihaljević, Vesna Tomaš, D. Vuković, K. Dugalić

\begin{abstract}
The aim of this study was to micropropagate three blue honeysuckle cultivars "Kalinka", "Polar Jewell" and "Balalaika". Driver and Kuniyuki medium (DKW) with different type and concentrations of plant hormones for in vitro shoot multiplication. For in vitro rooting were used Driver and Kuniyuki medium (DKW) and Murashige and Skoog medium (MS) was used with different concentrations of indol-3-butyric acid (IBA). The highest multiplication rate was obtained on DKW medium supplemented with $4 \mathrm{mg} \mathrm{L}^{-1}$ 6-benzylaminopurine (BA) and $1 \mathrm{mg} \mathrm{L}^{-1}$ indole-3-butyric acid (IBA) for cultivars "Balalaika" and "Polar Jewell", while of cultivar "Kalinka" with DKW medium and $2 \mathrm{mg} \mathrm{L}^{-1}$ 6-benzylaminopurine (BA) and $0.5 \mathrm{mg} \mathrm{L}^{-1}$ indole-3-butyric acid (IBA). The best microshoot rooting rates were obtained on DKW basal nutrient medium with $1 \mathrm{mg} \mathrm{L}^{-1}$ indol-3-butyric acid (IBA).
\end{abstract}

Key words: blue honeysuckle, in vitro, multiplication, rooting, micropropagation

\section{SAŽETAK}

Cilj ovog istraživanja bio je razviti protokol za mikrorazmnožavanje triju kultivara sibirske borovnice "Kalinka", "Polar Jewell" i "Balalaika". Medij Driver i Kuniyuki (DKW) s različitim vrstama i koncentracijama biljnih hormona korišten je za multiplikaciju izdanaka. Za in vitro ukorjenjivanje korišteni su mediji Driver i Kuniyuki (DKW) te mediji Murashige i Skoog (MS) s različitim koncentracijama indol 3-maslačne kiseline (IBA). Najviša stopa multiplikacije je postignuta na DKW mediju sa $4 \mathrm{mg} \mathrm{L}^{-1}$ 6-benzilaminopurina (BAP) i $1 \mathrm{mg} \mathrm{L}^{-1}$ indol 3-maslačne kiseline (IBA) kod kultivara "Balalaika" i "Polar Jewel", dok je kod kultivara "Kalinka" najviša multiplikacija postignuta na DKW mediju s $2 \mathrm{mg} \mathrm{L}^{-1}$ 6-benzilaminopurina (BAP) i $0.5 \mathrm{mg} \mathrm{L}^{-1}$ indol 3-maslačne kiseline (IBA). Najbolje ukorjenjivanje mikro izdanaka postignuto je na DKW mediju s $1 \mathrm{mg} \mathrm{L}^{-1}$ indol 3-maslačne kiseline (IBA).

Ključne riječi: sibirska borovnica, in vitro, multiplikacija, ukorjenjivanje, mikropropagacija 
Ines Mihaljević i sur.: Propagation of three Blue Honeysuckle

(Lonicera caerulea L.) cultivars in in vitro culture

\section{INTRODUCTION}

Blue honeysuckle (Lonicera cerulea L.) belongs to the family Caprifoliceae, native to Northeastern Asia. Lonicera cerulea has recently been one of the most respectable berry fruits. Fruits are good sources of antioxidants, bioactive compounds (Plekhanova, 2000), they contain high level of vitamins, anthocyanins and polyphenols (Skupien et al., 2007). Because of its nutraceutical and pharmaceutical values interest in their production is increased and blue honeysuckle production has been rapidly expanding. Traditional propagation methods of berry fruits are not efficient because propagation by cuttings is slow and labor intensive, and cutting propagation is not suitable for all cultivars because of lower rooting (Lyrene, 1981). Therefore it has been considered that micropropagation is the most effective method for rapid production of more plants in a shorter period of time with less labor and lower production costs. In vitro propagation of Lonicera cerulea has been investigated and micropropagation protocols have been described for different species (Sedlac and Paprštein, 2007; Fira et al., 2014; Dziedzic, 2008). These results are not suitable and applicable for every variety because the effectiveness of the medium for micropropagation is highly dependent on plant growth regulators and genotype specific of cultivars (Debnath, 2007). In order to determine the effect of Driver and Kuniyuki walnut medium (DKW) and Murashige i Skoog (MS) medium on multiplication rate and in vitro rooting on three cultivars of blue honeysucle, axillary buds were selected as explants and cultured in selected medium with plant hormones.

\section{MATERIALS AND METHODS}

The experiment was conducted in Plant tissue culture laboratory, Agricultural institute Osijek, Department for fruit-growing, during 2017. For the in vitro culture establishment, branches were cut from three honeysucle cultivars ("Kalinka", "Polar Jewell" and "Balalaika") taken from mature shrubs growing in the field. Standard sterilization of axillary buds was done with $70 \%$ ethanol for few seconds and after that sterilized with sodium hypochlorite $(\mathrm{NaClO})$. After sterilization procedure meristems with two or three primordial leaves were isolated and inoculated in culture medium containing the MS macro nutrients (Murashige and Skoog, 1962), SH micro nutrients (Schenk and Hildenbrandt, 1972), sucrose (30 g L-1), MS vitamins, agar (6 g L-1), 6-benzylaminopurine (BA) (0.5 mg L-1), 1-naphthaleneacetic acid (NAA) (0.01 mg L-1) and gibberellic acid (GA3) (0.5 mg L-1). Uncontaminated shoots 
were five months in subcultures for stabilization and then transferred to a DKW medium for proliferation, consisting of DKW macro, micro elements and vitamins (Driver and Kuniyuki, 1984), agar $\left(6 \mathrm{~g} \mathrm{~L}^{-1}\right)$ supplemented with different concentrations of cytokinins and auxins (Table 1.). Shoots length and multiplication index were determined. The multiplication rate was defined as the number of newly formed shoots per initial shoot tip after 28 days in culture. Axillary shoots were cut as microcuttings and rooted in half strength MS (Murashige and Skoog, 1962), and DKW media (Driver and Kuniyuki, 1984), supplemented with different concentration of indole-3-butyric acid (IBA) (Table 2.). Rooting parameters, such as number and length of roots were determined after 28 days. At all stages of experiments the media were supplemented with $6 \mathrm{~g} \mathrm{~L}^{-1}$ agar and $30 \mathrm{~g} \mathrm{~L}^{-1}$ sucrose. The $\mathrm{pH}$ of all media was adjusted to 5.8 before autoclaving the media at $121^{\circ} \mathrm{C}$ and $1.5 \mathrm{~atm}$ for $20 \mathrm{~min}$. During the experiment all cultures were kept in a growth chamber at $25^{\circ} \mathrm{C}$, with 16 hours photoperiod and 3500 lux of light intensity. All the multiplications and rooting experiments were designed with 3 replicates. Each replicate consisted of 10 explants placed in jars. Data from experiments were pooled and expressed as the mean. The data were analysed by ANOVA and significant differences were calculated using the LSD test. All data were analyzed using Statistica 8.0 software (StatSoft, Inc. 2007).

Table 1 Treatments with DKW medium (Driver and Kuniyuki, 1984) supplemented with different concentrations of cytokinins and auxins for multiplication of three blue honeysuckle cultivars.

Tablica 1. Tretmani s DKW medijem (Driver and Kuniyuki, 1984.) upotpunjeni različitim koncentracijama citokinina i auksina za multiplikaciju tri kultivara sibirske borovnice.

\begin{tabular}{|c|c|c|c|}
\hline Treatments & $\begin{array}{c}\text { 6-benzylaminopurine } \\
(\mathrm{BA}) \\
\left(\mathrm{mg} \mathrm{L}^{-1}\right)\end{array}$ & $\begin{array}{c}\text { indole-3-butyric acid } \\
(\mathrm{IBA}) \\
\left(\mathrm{mg} \mathrm{L}^{-1}\right)\end{array}$ & $\begin{array}{c}\text { 1-naphthaleneacetic } \\
\text { acid (NAA) } \\
\left(\mathrm{mg} \mathrm{L}^{-1}\right)\end{array}$ \\
\hline $\mathrm{T} 0$ & 0 & 0 & 0 \\
\hline $\mathrm{T} 1$ & 1 & 0.1 & - \\
\hline $\mathrm{T} 2$ & 1 & - & 1 \\
\hline $\mathrm{T} 3$ & 2 & 0.5 & - \\
\hline $\mathrm{T} 4$ & 2 & - & - \\
\hline $\mathrm{T} 5$ & 4 & 1 & 2 \\
\hline $\mathrm{T} 6$ & 4 & - & \\
\hline
\end{tabular}


Ines Mihaljević i sur.: Propagation of three Blue Honeysuckle (Lonicera caerulea L.) cultivars in in vitro culture

Table 2 Treatments with MS (Murashige and Skoog, 1962) and DKW (Driver and Kuniyuki, 1984) medium supplemented with different concentration of indole-3-butyric acid (IBA) for in vitro rooting of three blue honeysuckle cultivars.

Tablica 2. Tretmani s MS (Murashige and Skoog, 1962.) i DKW (Driver and Kuniyuki, 1984.) medijem, upotpunjeni s različitim koncentracijama indol 3-maslačne kiseline (IBA) za in vitro ukorjenjivanje tri kultivara sibirske borovnice.

\begin{tabular}{|c|c|}
\hline Treatments & indole-3-butyric acid (IBA) $\left(\mathrm{mg} \mathrm{L}^{-1}\right)$ \\
\hline $1 / 2$ DKW T0 & 0 \\
\hline $1 / 2$ DKW T1 & 0,5 \\
\hline $1 / 2$ DKW T2 & 1 \\
\hline $1 / 2$ MS T0 & 0 \\
\hline $1 / 2$ MS T1 & 0,5 \\
\hline $1 / 2$ MS T2 & 1 \\
\hline
\end{tabular}

\section{RESULTS AND DISCUSSION}

The medium used in our experiment, for multiplication and rooting in vitro, of blue honeysucle was different from most previously reported and our results were compared to those obtained for different protocols and cultivars. The previously reported methods mostly used MS media (Dziedzic, 2008; Sedlak and Paprštein, 2007; Wang et al., 2009) and WPM media (Hui et al., 2012). In the present study we micropropagated three blue honeysucle cultivars using DKW basal medium with different concentration of citokinins and auxins. According to a previous study DKW media was used for in vitro multiplication of Lonicera japonica (Osburn et al., 2009). The results concerning multiplication index and shoot length are presented in Table 3. The multiplication rate and shoot lenght varied depending on the cultivar and the concentration of BA and IBA. The highest numbers of new shoots were formed on medium T3 with BA concentration at $2 \mathrm{mg} \mathrm{L}^{-1}$ and $0.5 \mathrm{mg} \mathrm{L}^{-1}$ IBA for "Kalinka" cultivar. While "Balalaika" and "Polar Jewel" needed higher concentration of hormones and the best medium for multiplication was medium $\mathrm{T} 5$ with BA concentration at $4 \mathrm{mg} \mathrm{L}^{-1}$ and $1 \mathrm{mg} \mathrm{L}^{-1}$ IBA (Table 3.). Investigated cultivars responded differently to plant hormones composition regarding the 
length of new shoots. The highest plants $(8.22 \mathrm{~cm})$ were obtained for the cultivar "Kalinka" in medium T2 supplemented with $1 \mathrm{mg} \mathrm{L}^{-1} \mathrm{BA}$ and for the cultivars "Balalaika" $(6.28 \mathrm{~cm})$, "Polar Jewell" $(12.26 \mathrm{~cm})$ in medium T4 with BA concentration at $2 \mathrm{mg} \mathrm{L}^{-1}$ and $1.5 \mathrm{mg} \mathrm{L}^{-1}$ IBA. Although Dziedzic (2008) reported that high level of $\mathrm{BA}$ caused vitrification of honeysuckle, in our experiment it has been found that high BA concentration improved multiplication in "Polar Jewell" and "Balalaika". These results are not in accordance with the study of Sedlak and Paprštein (2007) who reported that high BA concentration $\left(4 \mathrm{mg} \mathrm{L}^{-1}\right)$ had a negative impact on the number of new shoots in the cultivar "Altaj", while the best multiplication rate was achieved with $2 \mathrm{mg} \mathrm{L}^{-1}$ of BA. Also, we found that IBA is more suitable than NAA for multiplication of selected cultivars because plants on medium supplemented with NAA were higher, thicker and with low multiplication rate (Table 3.). According to results we found that DKW medium was an appropriate medium for multiplication and this results are in accordance with the study of Osburn et al., (2009) who found that among DKW, MS and WPM basal medium, DKW proved to be the most effective for proliferation of Lonicera japonica and Lonicera maacki.

Table 3 Multiplication rates for three blue honeysucle cultivars on DKW medium with citokinin and auxins.

Tablica 3. Indeks multiplikacije triju kultivara sibirske borovnice na DKW mediju s citokininima i auksinima

\begin{tabular}{|c|c|c|c|c|c|c|}
\hline Cultivars & \multicolumn{2}{|c|}{ Kalinka } & \multicolumn{2}{c|}{ Balalaika } & \multicolumn{2}{c|}{ Polar Jewell } \\
\hline Treatments & $\begin{array}{c}\text { Mean shoot } \\
\text { lenght }(\mathrm{cm})\end{array}$ & $\begin{array}{c}\text { Multipl. } \\
\text { index }\end{array}$ & $\begin{array}{c}\text { Mean shoot } \\
\text { lenght }(\mathrm{cm})\end{array}$ & $\begin{array}{c}\text { Multipl. } \\
\text { index }\end{array}$ & $\begin{array}{c}\text { Mean shoot } \\
\text { lenght }(\mathrm{cm})\end{array}$ & $\begin{array}{c}\text { Multipl. } \\
\text { index }\end{array}$ \\
\hline T0 & $5.54 \mathrm{~b}$ & $1.07 \mathrm{e}$ & $6.01 \mathrm{ab}$ & $1.27 \mathrm{~d}$ & $13.13 \mathrm{a}$ & $1.00 \mathrm{e}$ \\
\hline T1 & $5.48 \mathrm{~b}$ & $1.80 \mathrm{c}$ & $5.18 \mathrm{~cd}$ & $1.43 \mathrm{~cd}$ & $8.78 \mathrm{~d}$ & $1.90 \mathrm{~cd}$ \\
\hline T2 & $8.22 \mathrm{a}$ & $1.33 \mathrm{~d}$ & $5.61 \mathrm{bc}$ & $1.57 \mathrm{~cd}$ & $12.20 \mathrm{~b}$ & $1.73 \mathrm{~cd}$ \\
\hline T3 & $5.37 \mathrm{~b}$ & $3.00 \mathrm{a}$ & $5.04 \mathrm{~d}$ & $1.70 \mathrm{c}$ & $8.30 \mathrm{~d}$ & $2.40 \mathrm{~b}$ \\
\hline T4 & $7.62 \mathrm{a}$ & $1.63 \mathrm{~cd}$ & $6.29 \mathrm{a}$ & $2.07 \mathrm{~b}$ & $12.26 \mathrm{ab}$ & $2.00 \mathrm{c}$ \\
\hline T5 & $4.56 \mathrm{c}$ & $2.50 \mathrm{~b}$ & $5.00 \mathrm{~d}$ & $2.10 \mathrm{~b}$ & $6.11 \mathrm{e}$ & $3.00 \mathrm{a}$ \\
\hline T6 & $5.56 \mathrm{~b}$ & $1.50 \mathrm{~cd}$ & $5.31 \mathrm{~cd}$ & $3.03 \mathrm{a}$ & $10.45 \mathrm{c}$ & $1.70 \mathrm{~d}$ \\
\hline
\end{tabular}

Means in columns with different letter are significantly different according to LSD test $(\mathrm{P}<0.05)$. 
Medium for rooting, free of plant growth regulator, did not show any root formation in all three cultivars. The DKW medium supplemented with $1 \mathrm{mg} \mathrm{L}^{-1}$ was the most effective for in vitro rooting of all three cultivars. The highest mean root number per plants was 4 ("Kalinka"), 4.10 ("Balalaika") and 3.56 ("Polar Jewell"). Roots produced in DKW medium supplemented with $1 \mathrm{mg} \mathrm{L}^{-1}$ IBA were the longest in all three cultivars: $5.31 \mathrm{~cm}$ ("Kalinka "), $5.20 \mathrm{~cm}$ ("Balalaika") and $4.70 \mathrm{~cm}$ ("Polar Jewell") (Table 4). Although previous researches recorded that MS medium used for in vitro rooting achieved good results (Krupa-Malkiewicz, 2014) in some protocols for rooting of Lonicera caerulea var. edulis on half strength MS there was no rooting (Karhu, 1997). In our study we found the poorest microshoot rooting rates: 1.18 ("Kalinka"), 0 ("Balalaika") and 0.70 ("Polar Jewell") on half strength MS basal medium with $0.5 \mathrm{mg} \mathrm{L}^{-1}$ IBA (Table 4).

In conclusion, DKW medium supplemented with BA $\left(2\right.$ and $\left.4 \mathrm{mg} \mathrm{L}^{-1}\right)$ and IBA $\left(0.5\right.$ and $\left.1 \mathrm{mg} \mathrm{L}^{-1}\right)$ gave the best multiplication rate and can be used in micropropagation of the three selected blue honeysucle cultivars. The best in vitro rooting of selected cultivars was achieved on DKW medium supplemented with $1 \mathrm{mg} \mathrm{L}^{-1}$. The results obtained in this study could be used for rapid propagation of selected cultivars, and for their commercial production.

Table 4 Rooting of three blue honeysucle cultivars on half MS and DKW medium with different concentration of IBA.

Tablica 4. Ukorjenjivanje triju kultivara sibirske borovnice na $1 / 2$ MS i DKW mediju s različitim koncentracijama IBA-e.

\begin{tabular}{|c|c|c|c|c|c|c|}
\hline Cultivars & \multicolumn{2}{|c|}{ Kalinka } & \multicolumn{2}{c|}{ Balalaika } & \multicolumn{2}{c|}{ Polar Jewell } \\
\hline Treatments & $\begin{array}{c}\text { Mean root } \\
\text { length (cm) }\end{array}$ & $\begin{array}{c}\text { Mean root } \\
\text { number per } \\
\text { shoot }\end{array}$ & $\begin{array}{c}\text { Mean root } \\
\text { length }(\mathrm{cm})\end{array}$ & $\begin{array}{c}\text { Mean root } \\
\text { number per } \\
\text { shoot }\end{array}$ & $\begin{array}{c}\text { Mean root } \\
\text { length }(\mathrm{cm})\end{array}$ & $\begin{array}{c}\text { Mean root } \\
\text { number per } \\
\text { shoot }\end{array}$ \\
\hline MS T0 & $0.00 \mathrm{e}$ & $0.00 \mathrm{~d}$ & $0.00 \mathrm{~d}$ & $0.00 \mathrm{~d}$ & $0.00 \mathrm{e}$ & $0.00 \mathrm{~d}$ \\
\hline MS T1 & $1.18 \mathrm{~d}$ & $0.67 \mathrm{c}$ & $0.00 \mathrm{~d}$ & $0.00 \mathrm{~d}$ & $0.71 \mathrm{~d}$ & $0.53 \mathrm{c}$ \\
\hline MS T2 & $2.55 \mathrm{c}$ & $0.67 \mathrm{c}$ & $0.67 \mathrm{c}$ & $1.20 \mathrm{c}$ & $2.55 \mathrm{c}$ & $0.67 \mathrm{c}$ \\
\hline DKW T0 & $0.00 \mathrm{e}$ & $0.00 \mathrm{~d}$ & $0.00 \mathrm{~d}$ & $0.00 \mathrm{~d}$ & $0.00 \mathrm{e}$ & $0.00 \mathrm{~d}$ \\
\hline DKW T1 & $3.18 \mathrm{~b}$ & $2.37 \mathrm{~b}$ & $3.28 \mathrm{~b}$ & $2.67 \mathrm{~b}$ & $3.25 \mathrm{~b}$ & $2.27 \mathrm{~b}$ \\
\hline DKW T2 & $5.32 \mathrm{a}$ & $4.00 \mathrm{a}$ & $4.22 \mathrm{a}$ & $3.12 \mathrm{a}$ & $4.70 \mathrm{a}$ & $3.57 \mathrm{a}$ \\
\hline
\end{tabular}

Means in columns with different letter are significantly different according to LSD test $(\mathrm{P}<0.05)$. 
Ines Mihaljević i sur.: Propagation of three Blue Honeysuckle (Lonicera caerulea L.) cultivars in in vitro culture

\section{REFERENCES}

DEBNATH, S.C. (2007.): Strategies to propagate Vaccinium nuclear stocks for the Canadian berry industry. Canadian Journal of Plant Science. 87:911-922.

DRIVER, J., AND KUNIYUKI, A. (1984.): In vitro propagation of Paradox walnut rootstock. HortScience. 19:507-509.

DZIEDZIC, E. (2008.): Propagation of blue honeysuckle (Lonicera caerulea var. Kamtschatica Pojark) in in vitro culture. Journal of Fruit and Ornamental plant Research. 16:93-100.

FIRA, AI., CLAPA, D., CRISTEA, V., PLOPA, C. (2014.): In vitro propagation of Lonicera kamtschatica. Agricultura-Science and Practice. 1-2: 89-90.

HUI, J.X., WEN, Z.S.C., HUA, L.Y., MING, X. (2012.): Comparative study on different methods for Lonicera japonica Thunb. micropropagation and acclimatization. Journal of Medicinal Plants Research. 6(27):4389-4393.

KARHU, S.K. (1997.): Rooting of blue honeysuckle microshoots. Plant Cell, Tissue and Organ Culture. 48:153-159.

KRUPA-MALKIEWICZ M., OCHMIAN, I. (2014.): Propagation of Blue Honeysuckles (Lonicera Caerulea L.) in in vitro culture. Journal of Basic \& Applied Sciences. 10:164-169.

LYRENE, P.M. (1981.): Juvenility and production of fast-rooting cuttings from blueberry shoot cultures. Journal of the American Society for Horticultural Science. 106: 396-398.

MURASHIGE, T., SKOOG, F. (1962.): A revised medium for rapid growth and bioassays withtobacco tissue cultures. Physiologia Plantarum. 15: 473-497.

OSBURN, L.D., YANG, X., LI, Y., CHENG Z.-M. (2009.): Micropropagation of Japanese Honeysuckle (Lonicera japonica) and Amur Honeysuckle ( $L$. maackii) by Shoot Tip Culture. Journal of Environmental Horticulture. 27(4):195-199.

PLEKHANOVA, M.N. (2000.): Blue honeysuckle (Lonicera caerulea L.). A new commercial berry crop for temperate climate: genetic resources and breeding. Acta Horticulturae. 538: 159-164.

SEDLAC, J. AND PAPRSTEIN, F. (2007.): In vitro propagation of blue honeysucle. Horticultural Science. 34 (4):746-750. 
SCHENK, R.V., HILDEBRANDT, A.C. (1972.): Medium and Techniques for Induction and Growth of Monocotyledonous and Dicotyledonous. Plant Cell Cultures. Canadian Journal of Botany. 50:199-204.

SKUPIEŃ, K., OSZMIAŃSKI, J., OCHMIAN, I., GRAJKOWSKI, J. (2007.): Characterization of selected physicochemical features of blue honeysuckle fruit cultivar Zielona. Polish Journal of Natural Science. 4:101-107.

WANG, X.Y., LI, Q. NIE, J. LI. (2009.): An Efficient Procedure for Regeneration from Leaf-derived Calluses of Lonicera macranthoides "Jincuilei", an Important Medicinal Plant. HortScience 44(3):746-750.

\section{Adresa autora - Authors address:}

Ines Mihaljević, e-mail. ines.mihaljevic@poljinos.hr,

Vesna Tomaš,

Dominik Vuković,

Agricultural institute Osijek,

Južno predgrađe 17, 31000 Osijek, Croatia

Krunoslav Dugalić,

Croatian agency for agriculture and food,

Vinkovačka 63 c, 31000 Osijek, Croatia 